\title{
PENGEMBANGAN KUESIONER PENILAIAN PROSES BELAJAR PROBLEM-BASED LEARNING DENGAN MODEL SPICES
}

\author{
Surya Akbar*, Mora Claramita**, Tri Nur Kristina*** \\ * Fakultas Kedokteran Universitas Islam Sumatera Utara, Medan \\ ** Fakultas Kedokteran Universitas Gadjah Mada, Yogyakarta \\ *** Fakultas Kedokteran Universitas Diponegoro, Semarang
}

\begin{abstract}
Background: Every medical education institution in Indonesia must used SPICES model as a strategy/approach on their curriculum. This accord with what is state in Standar Pendidikan Profesi Dokter Indonesia (SPPDI). Assessment of implementation of SPICES model in educational curriculum is bighly important in determining the direction of learning process underway. The aim of this study is to develop a questionnaire that helps medical educational institution to assess degree of implement of SPICES model on their curriculum.

Method: Questionnaire of Problem-based learning (PBL) learning process with SPICES model development made the two stages. First stage purpose was to develop questionnaire, while second stage was to validate of the questionnaire construct. First stage consists of three steps, i.e literature study, arrangements the items, and content validity. Construct validity of the questionnaire is done by used reliability test, and factor analysis test.

Results: Result from questionnaire development in the first stage was 29 items. Construct validity process in the stage two produced 17 items.

Conclusion: Assessment of PBL learning process with SPICES model questionnaire proven to be valid and reliable. Further investigation needs to assess stability of the questionnaire in other region.
\end{abstract}

Keywords: learning process assessment, SPICES model, Problem-Based Learning.

\section{ABSTRAK}

Latar Belakang: Setiap institusi pendidikan kedokteran di Indonesia diwajibkan untuk menggunakan pendekatan/ strategi model SPICES dalam kurikulum pendidikannya. Hal ini sesuai dengan apa yang tercantum dalam Standar Pendidikan Profesi Dokter Indonesia (SPPDI). Penilaian penerapan model SPICES dalam kurikulum pendidikan penting untuk menentukan arah dari proses pendidikan yang berlangsung. Penelitian ini bertujuan untuk mengembangkan kuesioner yang dapat membantu institusi pendidikan kedokteran untuk menilai derajat pelaksanaan model SPICES dalam kurikulumnya.

Metode: Pengembangan kuesioner penilaian proses belajar Problem-based learing (PBL) dengan model SPICES dilakukan dalam dua bagian besar yaitu bagian pertama bertujuan mengembangkan kuesioner, dan bagian kedua bertujuan melakukan validasi konstruk kuesioner. Bagian pertama pengembangan kuesioner terdiri dari tiga tahapan yaitu tahap studi pustaka, tahap menyusun item pernyataan kuesioner, dan tahap validasi isi kuesioner. Validasi konstruk kuesioner dilakukan dengan melakukan uji reabilitas, dan uji faktor analisis.

Hasil: Hasil dari proses pengembangan kuesioner bagian pertama menghasilkan 29 item pernyataan. Proses validasi konstruk pada bagian kedua menghasilkan 17 item pernyataan.

Kesimpulan: Kuesioner penilaian proses belajar Problem-based learning (PBL) dengan model SPICES terbukti valid dan reliabel. Penelitian lanjutan perlu dilakukan untuk menilai stabilitas dari kuesioner ini pada penggunaan di daerah lain.

Kata kunci: Penilaian proses belajar, model SPICES, Problem-Based Learning.

Korespondensi: dr.akbar9@gmail.com; No.HP: 081370717273 


\section{PENDAHULUAN}

Model SPICES (student centered learning, problem-based learning, integrated, community-based learning, elective, systematic) adalah suatu model yang dapat digunakan sebagai strategi/pendekatan dalam mengembangkan kurikulum pendidikan kedokteran. ${ }^{1}$ Penerapan model ini diharapkan dapat membentuk dokter yang memiliki kemampuan belajar mandiri, menyelesaikan masalah yang dihadapi, dan membentuk dokter yang sesuai dengan kebutuhan masyarakat. ${ }^{1}$

Di Indonesia, setiap institusi pendidikan kedokteran diharuskan menerapkan strategi/pendekatan yang menggunakan model SPICES. ${ }^{2}$ Penerapan model SPICES ini dilakukan dengan menggunakan metode pembelajaran Problem-Based Learning (PBL) sebagai proses belajarnya. Penerapan strategi/pendekatan model SPICES dalam kurikulum dimaksudkan untuk membentuk lulusan yang memenuhi standar kompetensi sebagai seorang dokter yang mampu memenuhi kebutuhan masyarakat. Baik tidaknya penerapan model SPICES dalam kurikulum pendidikan kedokteran akan mempengaruhi kualitas lulusan dari suatu institusi. Penilaian dengan model SPICES dapat menunjukkan arah dari proses pembelajaran yang dilakukan.

Penerapan model SPICES dalam kurikulum pendidikan kedokteran akan berjalan dengan baik bila dilakukan monitoring dan evaluasi yang berkelanjutan. Harden mengemukakan bahwa model SPICES tidak hanya dapat digunakan sebagai strategi/pendekatan yang digunakan untuk mengembangkan kurikulum, namun juga dapat digunakan sebagai panduan dalam menilai kurikulum yang sedang berjalan. ${ }^{1}$ Beberapa ahli dalam upaya menentukan derajat penerapan model SPICES pada suatu kurikulum melakukan beberapa cara penilaian. Van den Berg menilai penerapan model SPICES berdasarkan derajat penerapan masing-masing aspek SPICES pada setiap kegiatan perkuliahan. ${ }^{3}$ Derajat penerapan model SPICES pada setiap kegiatan perkuliahan kemudian akan dikalikan dengan persentase jam pelaksanaan kegiatan perkuliahan tersebut, sehingga hasil akhir perhitungan tersebut menggambarkan derajat pelaksanaan model SPICES pada masing-masing kegiatan perkuliahan. Changiz \& Yousefy menggunakan pendekatan yang berbeda dalam menilai penerapan model SPICES dalam kurikulum pendidikan Farmakologi, dimana mereka menggunakan kuesioner untuk menilai rangkaian derajat penerapan masing-masing aspek SPICES (misal: teacher-centered $>>$ student-centered). ${ }^{4}$ Changiz \& Yousefy menyarankan dilakukan penelitian lanjutan untuk meneruskan penelitian ini mengingat kuesioner tersebut hanya ditujukan untuk menilai aspek SPICES pada kurikulum tradisional, dan mereka juga menjumpai adanya beberapa item yang tumpang tindih dalam menilai aspek-aspek SPICES. ${ }^{4}$

Penjelasan diatas menunjukkan pentingnya bagi suatu institusi pendidikan kedokteran untuk menjamin terlaksananya kurikulum pendidikan berdasarkan model SPICES. Oleh karena itu diperlukan suatu alat pengukuran yang memberi kemudahan kepada pihak pengelola pendidikan kedokteran untuk mengetahui derajat pelaksanaan masing-masing aspek SPICES di institusinya. Penelitian ini bertujuan mengembangkan suatu kuesioner yang dapat digunakan untuk menilai derajat pelaksanaan model SPICES pada suatu kurikulum pendidikan kedokteran.

\section{METODE}

Secara garis besar pengembangan kuesioner penilaian proses belajar dilakukan dalam dua bagian, yaitu proses pengembangan kuesioner, dan proses validasi konstruk kuesioner.

\section{Bagian pertama}

Adapun tahap-tahap dalam bagian pertama pengembangan kuesioner penilaian proses belajar dengan model SPICES adalah studi pustaka, menyusun item pernyataan kuesioner, dan validasi isi berikut ini:

1. Tahap studi pustaka - studi pustaka dilakukan untuk menentukan definisi dan kriteria dari masing-masing aspek SPICES. Sumber yang digunakan untuk menentukan definisi dari masing-masing aspek SPICES berasal dari berbagai sumber baik berupa artikel atau buku., 7

2. Tahap menyusun item pernyataan kuesioneritem-item pernyataan disusun berdasarkan masing-masing definisi dari aspek SPICES. Jumlah item masing-masing aspek dibuat dengan 
proporsi yang sama, yaitu empat item disetiap aspeknya. Item dari masing-masing aspek dibagi kedalam dua fokus pernyataan, yaitu pernyataan yang berfokus pada proses belajar mengajar, dan pernyataan yang berfokus pada penilaian, sehingga masing-masing aspek memiliki dua item pernyataan yang berfokus pada proses belajar mengajar dan dua item pernyataan yang berfokus pada proses penilaian. Penilaian terhadap pernyataan kuesioner dilakukan dengan menggunakan lima poin skala Likert yaitu $1=$ "sangat tidak setuju", 2 = "tidak setuju", 3 = "netral", 4 = "setuju", dan 5 = "sangat setuju”.

3. Tahap validasi isi (Content Validity) - tahap validasi isi dilakukan dengan cara menilai kesesuaian item pernyataan dengan definisi dan kriteria yang telah ditentukan. Proses validasi isi ini dilakukan oleh ahli pendidikan kedokteran dengan kriteria telah memiliki pengalaman bekerja dalam bidang pendidikan kedokteran selama lebih dari 5 tahun. Jumlah ahli yang digunakan untuk validasi isi merujuk pada pernyataan Fraenkel yang mengatakan bahwa validasi isi dapat dilakukan pada satu atau lebih penilai. ${ }^{8}$ Proses validasi isi ini juga memungkinkan kedua ahli untuk memberi masukan dalam hal penambahan jumlah item pernyataan, ataupun perubahan kalimat pernyataan item kuesioner sehingga kuesioner tersebut dapat secara tepat menilai masing-masing aspek SPICES. Proses ini dilakukan berulang kali hingga kedua ahli tersebut menganggap item kuesioner telah dapat mengukur masing-masing aspek SPICES. Hasil akhir proses ini menghasilkan 29 item pernyataan.

\section{Bagian kedua}

Bagian kedua dari proses membuat kuesioner ini adalah melakukan validasi konstruk dari kuesioner yaitu dengan melakukan uji reabilitas, dan uji faktor analisis. Validasi konstruk kuesioner dilakukan setelah data dari uji coba kueisoner diperoleh. Uji coba dilakukan kepada seluruh mahasiswa tahun ketiga FK UGM dari tiga program studi (pendidikan kedokteran, ilmu keperawatan, dan gizi kesehatan) yang berjumlah 524 orang. Mahasiswa tahun ketiga dipilih dikarenakan mereka telah cukup lama merasakan proses belajar di FK UGM sehingga mereka dapat memberi gambaran penilaian proses belajar yang berlangsung. Mahasiswa yang bersedia mengikuti penelitian ini diminta untuk menandatangani lembar persetujuan yang diberikan.

\section{HASIL DAN PEMBAHASAN}

Proses penyusunan item dari definisi dan kriteria masingmasing aspek SPICES terbentuk 24 item pernyataan. Jumlah item kuesioner bertambah menjadi 29 item pernyataan setelah melalui tahap validasi isi (tabel 1).

Tabel 1. Item kuesioner setelah validasi isi

\section{ASPEK}

Student-Centered Learning

\section{ITEM PERNYATAAN}

1 Saya menentukan tujuan belajar berdasarkan masalah (skenario belajar) yang didiskusikan bersama teman-teman dan tutor.

2. Staf pengajar (tutor/dosen) mendorong saya menentukan kebutuhan belajar dengan cara menentukan tujuan belajar yang ingin saya capai.

3. Pihak fakultas memberi waktu tertentu agar saya dapat melakukan proses belajar mandiri.

4. Saya diberi waktu cukup untuk mempersiapkan diri dalam menghadapi penilaian hasil belajar.

5. Saya mendapat informasi yang cukup mengenai hasil yang diharapkan dari proses belajar yang dilakukan sehingga saya dapat mempersiapkan proses belajar dengan baik.

Problem-Based Learning

6. Masalah (skenario) yang disampaikan dalam tutorial, mendorong saya untuk memahami materi yang dipelajari. 
Lanjutan Tabel 1. Item kuesioner setelah validasi isi

\section{ASPEK}

\section{ITEM PERNYATAAN}

7. Masalah yang disampaikan dalam tutorial, membantu saya memahami penerapan ilmu kedokteran dalam menjelaskan suatu masalah kesehatan.

8. Tenaga pengajar (dosen/tutor) memberikan feedback (umpan balik) disetiap akhir proses belajar.

9. Tenaga pengajar (dosen/tutor) memberi umpan balik (feedback) yang meningkatkan pengetahuan/keterampilan saya.

Integrated Learning

10. Saya memahami materi yang diberikan dengan melihatnya dari berbagai disiplin ilmu yang relevan

11. Proses belajar yang dilakukan, berfokus pada hubungan dari beberapa disiplin ilmu terhadap materi yang dipelajari.

12. Materi yang diujikan dalam ujian akhir terdiri dari beberapa disiplin ilmu yang saling berkaitan.

13. Ujian yang dilakukan menilai pemahaman saya terhadap hubungan beberapa disiplin ilmu pada satu materi belajar.

Community-Based Learning
14. Materi yang dipelajari berfokus pada masalah dan penanganan masalah kesehatan yang nyata dijumpai di masyarakat.

15. Proses belajar yang dilakukan memungkinkan saya untuk berinteraksi langsung dengan permasalahan kesehatan di masyarakat.

16. Proses belajar lebih menekankan pada tindakan promotif dan preventif dalam penanganan masalah kesehatan.

17. Materi yang diujiankan berkaitan dengan masalah kesehatan yang sering dijumpai di masyarakat.

18. Penguasaan pengetahuan dan keterampilan melakukan penanganan masalah kesehatan di masyarakat (promotif, preventif, kuratif) adalah materi dari ujian yang dilakukan.

\section{Electives}

19. Saya dapat memilih materi belajar yang ingin saya pelajari lebih dalam.

20. Saya dapat mengusulkan metode pengajaran yang ingin saya jalani.

21. Saya dapat mengusulkan topik/materi apa yang penting untuk dinilai.

22. Topik/materi yang akan diujikan sesuai dengan materi yang saya usulkan untuk diuji.

Systematic

23. Pengalaman belajar yang diberikan oleh fakultas sesuai dengan tujuan belajar yang disampaikan.

24. Pengalaman belajar yang diberikan oleh fakultas sesuai dengan kemampuan yang dibutuhkan untuk menjadi seorang dokter umum.

25. Proses belajar meningkatkan pengetahuan saya secara bertahap.

26. Materi belajar diberikan secara bertahap dari yang simpel (mudah) ke kompleks (sulit).

27. Materi belajar diberikan secara bertahap dimulai dari yang fisiologis ke patologis.

28. Penilaian hasil belajar sesuai dengan pengalaman belajar yang saya peroleh.

29. Penilaian hasil belajar sesuai dengan tujuan belajar yang telah disampaikan. 
Uji coba kepada mahasiswa tahun ketiga FK UGM diperoleh 451 mahasiswa $(86,07 \%)$ yang bersedia mengikuti penelitian ini dan mengisi kuesioner secara lengkap. Data yang digunakan untuk menguji validitas konstruk kuesioner berasal dari total skor masing-masing aspek SPICES.

\section{Uji reabilitas}

Penilaian reabilitas kuesioner dilakukan pada tingkatan masing-masing aspek dan dilanjutkan pada tingkat keseluruhan kuesioner. Kuesioner dikatakan memiliki reabilitas yang baik bila memiliki nilai Cronbach alpha $>0,7$. Item yang terbukti tidak reliabel akan dikeluarkan dari kuesioner. Syarat pengeluaran item yang tidak reliabel adalah bila item memiliki nilai total korelasi (corrected item-total correlation) rendah $(<0,3)$, dan syarat kedua adalah bila item tersebut yang memenuhi syarat pertama dikeluarkan maka nilai Cronbach alpha sub skala akan meningkat. ${ }^{9}$ Proses ini akan dilakukan terus menerus hingga tidak ada item dalam masing-masing aspek yang memenuhi kedua syarat pengeluaran item. Hasil uji reabilitas tingkat sub skala diperoleh tiga item yang tidak reliabel sehingga dikeluarkan dari kuesioner yaitu item no.1, 2, dan 22. Nilai Cronbach alpha pada keseluruhan kuesioner setelah item tersebut dikeluarkan adalah 0,859 .

\section{Uji faktor analisis}

Faktor analisis dilakukan untuk melihat kesesuaian item pernyataan dalam mengukur masing-masing aspek SPICES. Uji faktor analisis ini juga dilakukan dari tingkatan masing-masing aspek dan dilanjutkan pada tingkat keseluruhan kuesioner. Aspek yang memiliki dua faktor setelah dilakukan uji faktor analisis akan dilakukan usaha untuk menghasilkan satu buah faktor yaitu dengan cara mengeluarkan item yang tidak sesuai. Syarat sebuah item untuk dapat dikeluarkan dari kuesioner adalah item yang memiliki nilai extraction (korelasi item dengan faktor yang terbentuk) yang terendah. ${ }^{10}$ Bila masih terbentuk dua faktor pada masing-masing aspek saat dilakukan analisis faktor maka item yang memiliki nilai extraction terendah akan dikeluarkan. Hal ini akan dilakukan terus menerus sampai hanya terbentuk satu faktor pada masingmasing aspek. Hasil uji faktor analisis pada tingkatan aspek diperoleh 21 item yang terbukti baik menilai masing-masing aspek. Lima item yang dikeluarkan dari kuesioner setelah analisis faktor tingkat aspek adalah item no. 6, 7, 23, 24, dan 27.

Analisis faktor tingkat keseluruhan kuesioner dilakukan setelah analisis faktor tingkat aspek selesai dilakukan. Kriteria pengeluaran item pada tingkat keseluruhan kuesioner adalah bila item berada tidak pada aspek dimana seharusnya ia berada. Hasil analisis faktor pada tingkat keseluruhan kuesioner didapatkan empat item yang tidak berada pada aspek dimana ia seharusnya berada yaitu item no. 17, 18, 28, 29. Keempat item tersebut kemudian dikeluarkan dari kuesioner. Analisis faktor setelah empat item tersebut dikeluarkan menghasilkan enam buah faktor yang menilai masingmasing aspek SPICES dengan nilai Kaiser-Meyer-Olkin $(\mathrm{KMO})$ berada diatas 0,6 yaitu 0,71. Nilai KMO >0,6 menunjukkan bahwa data yang digunakan cukup kuat untuk dilakukan faktor analisis. ${ }^{10}$ Item kuesioner penilaian proses belajar PBL dengan model SPICES setelah dilakukan proses validasi konstruk berjumlah 17 item (tabel 2).

Tabel 2. Item kuesioner hasil validasi konstruk

\section{ASPEK}

Student-Centered Learning

\section{ITEM PERNYATAAN}

1. Pihak fakultas memberi waktu tertentu agar saya dapat melakukan proses belajar mandiri.

2. Saya diberi waktu cukup untuk mempersiapkan diri dalam menghadapi penilaian hasil belajar.

3. Saya mendapat informasi yang cukup mengenai hasil yang diharapkan dari proses belajar yang dilakukan sehingga saya dapat mempersiapkan proses belajar dengan baik. 
Lanjutan Tabel 2. Item kuesioner hasil validasi konstruk

\section{ASPEK}

Problem-Based Learning

\section{ITEM PERNYATAAN}

4. Tenaga pengajar (dosen/tutor) memberikan feedback (umpan balik) disetiap akhir proses belajar.

5. Tenaga pengajar (dosen/tutor) memberi umpan balik (feedback) yang meningkatkan pengetahuan/keterampilan saya.

\begin{tabular}{|c|c|}
\hline \multirow[t]{4}{*}{ Integrated Learning } & $\begin{array}{l}\text { 6. Saya memahami materi yang diberikan dengan melihatnya dari berbagai } \\
\text { disiplin ilmu yang relevan. }\end{array}$ \\
\hline & $\begin{array}{l}\text { 7. Proses belajar yang dilakukan, berfokus pada hubungan dari beberapa } \\
\text { disiplin ilmu terhadap materi yang dipelajari. }\end{array}$ \\
\hline & $\begin{array}{l}\text { 8. Materi yang diujikan dalam ujian akhir terdiri dari beberapa disiplin ilmu } \\
\text { yang saling berkaitan. }\end{array}$ \\
\hline & $\begin{array}{l}\text { 9. Ujian yang dilakukan menilai pemahaman saya terhadap hubungan } \\
\text { beberapa disiplin ilmu pada satu materi belajar. }\end{array}$ \\
\hline \multirow[t]{3}{*}{ Community-Based Learning } & $\begin{array}{l}\text { 10. Materi yang dipelajari berfokus pada masalah dan penanganan masalah } \\
\text { kesehatan yang nyata dijumpai di masyarakat. }\end{array}$ \\
\hline & $\begin{array}{l}\text { 11. Proses belajar yang dilakukan memungkinkan saya untuk berinteraksi } \\
\text { langsung dengan permasalahan kesehatan di masyarakat. }\end{array}$ \\
\hline & $\begin{array}{l}\text { 12. Proses belajar lebih menekankan pada tindakan promotif dan preventif } \\
\text { dalam penanganan masalah kesehatan. }\end{array}$ \\
\hline \multirow[t]{3}{*}{ Electives } & 13. Saya dapat memilih materi belajar yang ingin saya pelajari lebih dalam. \\
\hline & 14. Saya dapat mengusulkan metode pengajaran yang ingin saya jalani. \\
\hline & 15. Saya dapat mengusulkan topik/materi apa yang penting untuk dinilai. \\
\hline \multirow[t]{2}{*}{ Systematic } & 16. Proses belajar meningkatkan pengetahuan saya secara bertahap. \\
\hline & $\begin{array}{l}\text { 17. Materi belajar diberikan secara bertahap dari yang simpel (mudah) ke } \\
\text { kompleks (sulit). }\end{array}$ \\
\hline
\end{tabular}

Standar pendidikan profesi dokter di Indonesia mengharuskan setiap institusi pendidikan kedokteran menggunakan pendekatan/strategi model SPICES dalam kurikulumnya. Harden menjelaskan bahwa dengan menggunakan model SPICES sebagai pendekatan dalam mengembangkan kurikulum pendidikan, arah dan tujuan dari pendidikan yang dilakukan akan menjadi lebih jelas terlihat. ${ }^{1}$ Penilaian proses belajar PBL dengan model SPICES dapat dilakukan dengan beberapa cara, yaitu dengan melakukan observasi untuk melihat derajat pelaksanaan masing-masing aspek SPICES pada setiap kegiatan perkuliahan seperti yang dilakukan oleh van den Berg, ${ }^{3}$ atau menggunakan kuesioner yang diberikan kepada mahasiswa seperti yang dilakukan oleh Changiz \& Yousefy. ${ }^{4}$
Penilaian menggunakan cara yang dilakukan oleh van den Berg memiliki kekurangan yaitu penilaian hanya dilakukan berdasarkan observasi terhadap pelaksanaan masing-masing kegiatan perkuliahan. Observasi yang dilakukan dapat memunculkan sifat subjektifitas, sehingga penilaian tersebut dapat menimbulkan bias terhadap hasilnya. Kuesioner yang dikembangkan oleh Changiz \& Yousefy sudah lebih baik dibandingkan dengan cara penilaian yang dilakukan oleh van den Berg, dimana penilaian dilakukan berdasarkan pada persepsi mahasiswa terhadap proses belajar yang terjadi. Penilaian dengan menggunakan persepsi mahasiswa dikatakan lebih baik karena mahasiswa merupakan individu yang mengalami langsung proses belajar dalam suatu institusi pendidikan, sehingga persepsi yang muncul memang mencerminkan proses belajar yang dilaksanakan oleh institusi tersebut. Ketidaksesuaian 
kuesioner yang dikembangkan oleh Changiz \& Yousefy untuk digunakan di Indonesia adalah penilaian yang ditujukan untuk menilai proses belajar pada kurikulum tradisional, dan dijumpai item-item dalam kuesioner yang tumpah tindih dalam menilai masing-masing aspek SPICES. ${ }^{4}$ Penelitian ini bertujuan untuk melanjutkan penelitian yang dilakukan oleh Changiz \& Yousefy, yaitu dengan mengembangkan suatu kuesioner yang dapat digunakan untuk menilai proses pembelajaran $\mathrm{PBL}$ dengan menggunakan model SPICES di Indonesia.

Kuesioner yang menggunakan skala Likert sebagai penilaiannya memang dapat menimbulkan dua interpretasi terhadap hasil yang diperoleh. Oleh karenanya, hasil kuesioner penilaian proses belajar PBL dengan model SPICES dapat pula digambarkan dengan dua cara yaitu: melihat derajat pelaksanaan keseluruhan aspek SPICES pada suatu institusi yaitu dengan menghitung total skor dari kuesioner, dan melihat derajat kesetujuan responden terhadap pelaksanaan masingmasing item pada setiap aspek SPICES secara tersendiri yaitu dengan menghitung rerata pada masing-masing item. Cara yang pertama memberikan data berskala interval, sedangkan cara yang kedua memberikan data berskala ordinal. Pemilihan cara penilaian kuesioner ini tergantung dari sudut pandang peneliti lain dalam menginterpretasikan data hasil yang diperoleh. Kedua perspektif tersebut adalah benar asalkan sesuai dengan tujuan dari penelitian yang dilakukan.

Peneliti menganjurkan merubah beberapa item pernyataan kuesioner kedalam kalimat negatif bila ingin digunakan. Hal ini dilakukan untuk mencegah terjadinya bias dalam pengisian kuesioner dan juga mencegah kesempatan responden untuk mengisi kuesioner dengan hanya mengurutkan nilai saja. Perubahan sifat kalimat tersebut harus disertai dengan penilaian yang terbalik untuk tiap skala Likert-nya. Penilaian skala Likert pada kalimat negatif tersebut akan menjadi $1=$ "sangat setuju" sampai dengan 5 = "sangat tidak setuju". Peneliti menganjurkan untuk melakukan analisis faktor kembali bila dilakukan perubahan terhadap sifat kalimat kuesioner.

Keterbatasan dari kuesioner ini adalah hanya dapat ditujukan pada institusi pendidikan yang telah menerapkan metode pembelajaran PBL dalam kurikulumnya. Perlu untuk dilakukan penelitian lanjutan dalam upaya melihat stabilitas penggunaan kuesioner ini di daerah lain. Uji coba keterbacaan sebelum menggunakan kueisoner ini di daerah lain perlu untuk dilakukan, mengingat perbedaan dalam hal karakteristik responden masing-masing daerah yang berbeda-beda.

\section{KESIMPULAN}

Kuesioner penilaian proses belajar PBL dengan menggunakan model SPICES terdiri dari 17 item pernyataan. Kuesioner tersebut terbukti valid baik secara isi maupun secara konstruk dalam penelitian ini. Penggunaan kuesioner ini untuk penelitian lainnya perlu dilakukan beberapa penyesuian yaitu meliputi uji keterbacaan, merubah sifat kalimat pernyataan, dan melakukan analisis faktor. Penelitian lebih lanjut perlu untuk dilakukan sehingga stabilitas dari penggunaan kuesioner ini di daerah lain dapat dipastikan. Diharapkan dengan dikembangkannya kuesioner ini dapat memudahkan institusi pendidikan kedokteran untuk melakukan penilaian terhadap proses belajar PBL yang menerapkan model SPICES.

\section{PERSETUJUAN ETIKA}

Penelitian ini telah mendapatkan persetujuan etik dari Komite Etik Kedokteran dan Kesehatan Fakultas Kedokteran Universitas Gadjah Mada.

\section{DAFTAR PUSTAKA}

1. Harden, RM, Sowden, S \& Dunn, WR. Educational strategies in curriculum development: SPICES model. Medical Education. 1984; 18: 284-97.

2. Konsil Kedokteran Indonesia. Standar Pendidikan Profesi Dokter Indonesia. Jakarta: Konsil Kedokteran Indonesia; 2012.

3. Van den Berg, H. Rating of SPICES criteria to evaluate and compare curricula. Med Teach. 2004; 26(4): 381-4.

4. Changiz, T \& Yousefy, A. A course evaluation tool based on SPICES model, and its application to evaluation of medical pharmacology course. Journal of Medical Education. 2006; 8(2): 111-20.

5. Harden, RM \& Davis, MH. The continuum of problem-based learning. Medical Teacher. 1998; 20(4): 317-22.

6. Harden, RM. The integration ladder: a tool for curriculum planning and evaluation. Medical Education. 2000; 34: 551-57. 
7. Dent, JA \& Harden, RM. A Practical Guided for Medical Teachers third edition. Edinburgh: Churchill Livingstone Elsevier; 2009.

8. Fraenkel, JR, Wallen, NE \& Hyun, HH. How to Design and Evaluate Research in Education Eight Edition. New York: McGraw-Hill; 2012.
9. Cohen, L, Manion, L \& Morrison, K. Research methods in education. London: Routledge; 2011.

10. Meyers, LS, Gamst, G \& Guarino, AJ. Applied multivariate research, design and interpretation. California: SAGE publictions, Thousand Oaks: 2006. 